Бямбасүрэн Ганцэцэг, Баянмөнх Мягмаргэрэл, Мөрнэрэн Туяа, Баясгалан Хулан, Батчулуун Хонгорзул*

Органик химийн лаборатори, Хими, Химийн Технологийн Хүрээлэн, Шинжлэх Ухааны Академи, Улаанбаатар 13330, Монгол улс

*E-mail: khongorzul.b@mas.ac.mn ORCID: 0000-0002-5953-3667

Хүлээн авсан: 21.10.2021 Хяналтанд: 24.10.2021 Хэвлэлтэнд авсан: 28.12 .2021

Хураангуй: ЭнэхүҮ ажлын хүрээнд Монгол орны Цагаан-Элсний ордын нефтийн хатуу парафиныг исэлдүүлэн гадаргуугийн идэвхт үйлчлэлтэй угаагч бодисын гол түүхий эд болох нийлэг тосны хүчил гарган авах судалгааг явуулсан. Судлагдаж буй нефтийн 350-450ㅇ-д нэрэгдэх тосны фракц нь 20.06 мас.\% -ийг эзлэх бөгөөд тосны фракциас карбамидаар комплекс үүсгэх замаар хатуу парафиныг 34.28 хувийн гарцтайгаар ялган авав. Хатуу парафин нь найрлагандаa $\mathrm{C}_{17}-\mathrm{C}_{34}$ бүхий нүүрстөрөгчийн атом агуулсан, молекул массын тархалтаараа унимодаль шинжтэй байв. Нефтийн тосны фракцаас ялгасан н-парафиныг молекул хүчилтөрөгчөөр исэлдүүлэх процессын зохимжтой горимыг янз бүрийн параметрүүдээс хамааруулан математик загварчлалын аргаар тооцоолоход катализаторын хэмжээ 0.1 мас.\% (парафинд тооцсоноор), хүчилтөрөгчийн урсгалыг 0.6 л/мин гэж тодорхойлов. Уг горимын дагуу Цагаан-Элсний ордын нефтиэс ялгасан хатуу парафиныг исэлдүүлэхэд 44.09 мас.\% гарцтай нийлэг тосны хүчлийн фракцийг гарган авсан. Нийлэг тосны хүчлийн нил улаан туяаны спектроскопийн шинжилгээгээр монокарбон хүчлүүд зонхилсон хүчилтөрөгч агуулсан нэгдлүүд үүсэж байгааг тогтоосон бөгөөд хийн хроматограф-масс спектрометрийн судалгаагаар эдгээр тосны хүчил нь $\mathrm{C}_{7}-\mathrm{C}_{26}$ бүхий нүүрстөрөгчийн атом агуулсан дээд тосны хүчлүүд болохыг тодорхойлов. Судалгааны дүнд манай орны нефтийн хатуу парафиныг исэлдүүлэн төрөл бүрийн угаагч бодисын үйлдвэрлэлд өргөнөөр хэрэглэгддэг суурь түүхий эд болох нийлэг тосны хүчлийг гарган авах боломжтой гэж дүгнэлээ.

Түлхүүр үг: нийлэг тосньл хүчил, парафин, нефть, катализатор, оксидат, математик загварчлал.

\section{ОРШИЛ}

Нефть нь олон төрлийн нүүрсустөрөгчдийн хольцоос тогтох бөгөөд түлш, шатахуун үйлдвэрлэхээс гадна төрөл бүрийн уусгагч бодис, тослох материал, гадаргуугийн идэвхт бодисууд (ГИБ) болон хуванцар материал үйлдвэрлэлийн үндсэн түүхий эд болдог. Нефтийн хатуу парафиныг исэлдүүлэн төрөл бүрийн ГИБ-ууд болох саван, угаагч бодис, түрхлэг тосны үйлдвэрлэлийн үндсэн түүхий эд болох нийлэг тосны хүчлүүд (НТХ)-ийг гарган авдаг бөгөөд эдгээр нь бидний өдөр тутмын амьдралд болон бусад аж үйлдвэрийн салбарт өргөнөөр хэрэглэгддэг байна $[1$, 2]. Нефтийн хатуу парафиныг исэлдүүлэх замаар гарган авсан өндөр молекулт монокарбон хүчлүүдийн 70\%-ийг алифатик спиртүүд болон гадаргуугийн идэвхт үйлчлэлтэй нийлэг угаагч бодисын үйлдвэрлэлд, 15\%-ийг түрхлэг тос, чанар сайжруулагч нэмэлтүүд гарган авахад, үлдсэн $15 \%$ нь бусад салбарын хэрэглээнд зарцуулагддаг гэсэн тооцоо, судалгаa байдаг [3]. Мөн хүчилтөрөгч агуулсан янз бүрийн уусгагч, бодисуудын үйлдвэрлэлийн үндэс суурь нь болж өгдөг, тухайлбал хүчил, спирт, альдегид, кетон гэх мэт. Парафинаас тосны хүчил гарган авах урвал парафиныг исэлдүүлэх, исэлдэлтийн бүтээгдэхүүнийг боловсруулах гэсэн 2 үе шаттайгаар явагддаг $[4,5]$. Исэлдэх процесс нь урвалын нөхцөлөөс ихээхэн хамаaрах ба катализаторын хэмжээ, төрөл, исэлдүүлэгч агентын урсгалын хурд, хугацаа, парафины цэвэршилтийн зэрэг гэх мэт олон параметрүүдээс хамаарна $[6,7]$. Парафиныг исэлдүүлэх процессын дүнд гарган авсан оксидат нь исэлдсэн парафин (тосны хүчил), хувиралд ороогүй үлдсэн парафин (60\%), саармаг болон хүчиллэг шинжтэй хүчилтөрөгчит нэгдлүүдийн хольц юм. НТХ гарган авах урвалын дүнд янз бүрийн молекул масстай хүчлийн хольцыг үүсгэдэг ба үйлдвэрлэлийн эцсийн бүтээгдэхүүн нь дан хүчлүүд биш, тэдгээрийн фракцууд байдаг. $\mathrm{C}_{5}-\mathrm{C}_{9}$ бүхий фракцийг агаарын тээврийн хөдөлгүүрт синтетик тос гарган авахад, $\mathrm{C}_{7-}$ $\mathrm{C}_{9}$ фракцийг пластификатор, гадаргуугийн идэвхт бодис, деэмульгатор, флотореагентын үйлдвэрлэлд, $\mathrm{C}_{10}-\mathrm{C}_{16}$ фракцийг савангийн үйлдвэрлэлд (гар нүүрийн савангийн үйлдвэрлэлд), $\mathrm{C}_{17}-\mathrm{C}_{20}$ фракцийг савангийн үйлдвэрт (эдийн саван), лак, будаг, тосолгооны материалууд гарган авахад ашигладаг $[4,7]$. Монгол орны Дорнод аймгийн Матад сумын сав газар дахь Тамсагбулагийн орд, Дорноговь аймгийн Зүүнбаян сумын нутаг дэвсгэрт Зүүнбаян, Цагаан-Элсний нефтийн ордууд тархан байршсан бөгөөд баталгаат зэрэглэлийн нөөц 332.64 сая тонн, ашиглалтын 
баталгаат зэрэглэлийн нөөц 43.25 сая тонн гэж тогтоогоод байна $[8,9]$. Өмнөх судалгааны дүнд бид Монгол оронд олборлогдож буй нефтийн физикхимийн шинж чанар, найрлага, бүтэц, нүүрсустөрөгчдийн бүрэлдэхүүнийг нарийвчлан судалж, эдгээр нефть нь хөнгөн фракцийн гарц болон өндөр молекулт нэгдлийн агуулга бага, хатуу парафины агуулга өндөртэй, өтгөн, царцамтгай нефть болохыг судлан тогтоосон $[10,11]$. Иймээс парафины агуулга өндөртэй Цагаан-Элсний ордын нефтийн онцлог шинж чанарт тулгуурлан нефтийн тосны фракцаас хатуу парафин ялган авч, цааш исэлдүүлэн саван болон бусад төрлийн угаагч бодисын үйлдвэрлэлд ашиглагддаг НТХ-ийг гарган авах боломжийг судаллаа. Энэхүу судалгаа нь нефтийн үйлдвэр бий болж буй өнөө үед нүүрсустөрөгчдийн түүхий эдийг ашиглан химийн үйлдвэрлэлийн бүтээгдэхүүн гарган авах боломж, үндэс суурийг бий болгох, нефть химийн синтезийг хөгжүүлэх практик ач холбогдолтой юм.

Энэхүу судалгааны ажлын зорилго нь өндөр парафинт Цагаан-Элсний ордын нефтиэс хатуу парафиныг ялган авч улмаар катализаторын оролцоотой молекул хүчилтөрөгчөөр исэлдүүлэн үйлдвэрлэлийн төрөл бүрийн салбарт ашиглагдах гадаргуугийн идэвхт үйлчлэлтэй НТХ-ийг гарган авч, найрлага шинж чанарыг судлахад оршино.

\section{СУДАЛГААНЫ МАТЕРИАЛ, АРГА ЗУЙ}

Дорноговь аймгийн Зүүнбаян сумын нутагт орших Цагаан-Элсний ордын XIV талбайн 1120 - 1130 м гүний нефтийн дээжийг судалгааны объектоор ашиглав. Нефтийн физик-химийн үзүүлэлтүүд болон бүлгийн бүрэлдэхүүнийг уламжлалт болон стандарт аргуудын дагуу тодорхойлов [12]. Нефтиэс нийлэг тосны хүчил гарган авах туршилтыг дараах ерөнхий схемийн дагуу явуулж Зураг 1-д үзүүлэв.

Урьдчилан усгүйжүүлж, механик хольцоос салгасан нефтийн дээжийг лабораторийн нөхцөлд буцалж эхлэхээс $200^{\circ} \mathrm{C}$ хүртэл атмосферын даралтанд бензиний, $200-350^{\circ} \mathrm{C}$-д дизелийн, $350-450^{\circ} \mathrm{C}$-д тосны фракцийг вакуум орчинд 2 мм м.у.б. даралтанд тус тус нэрж фракцийн найрлагыг тодорхойлов. $350-450^{\circ} \mathrm{C}$-д нэрэгдэх тосны фракциас (изооктан - уусгагч, идэвхжүүлэгч этанол) карбамидаар комплекс үүсгэх замаар хатуу парафиныг ялган, гарц болон физик-химийн ҮзүҮлэлтүүдийг тодорхойлов $[13,14]$.

Цагаан-Элсний ордын нефтиэс ялган авсан хатуу парафиныг синтезийн реакторт өмнө тогтоосон горимын дагуу $[4,15,16] \quad 0.3$ мас.\% $\mathrm{KMnO}_{4}-$ катализаторын оролцоотой атмосферийн даралтанд $105-130^{\circ} \mathrm{C}$ хувьсах температурын нөхцөлд $0.4-0.6$ л/мин молекул хүчилтөрөгчийн урсгалаар исэлдүүлсэн. Исэлдүүлэх процессын тохиромжтой горимыг математик загварчлалын аргыг ашиглан

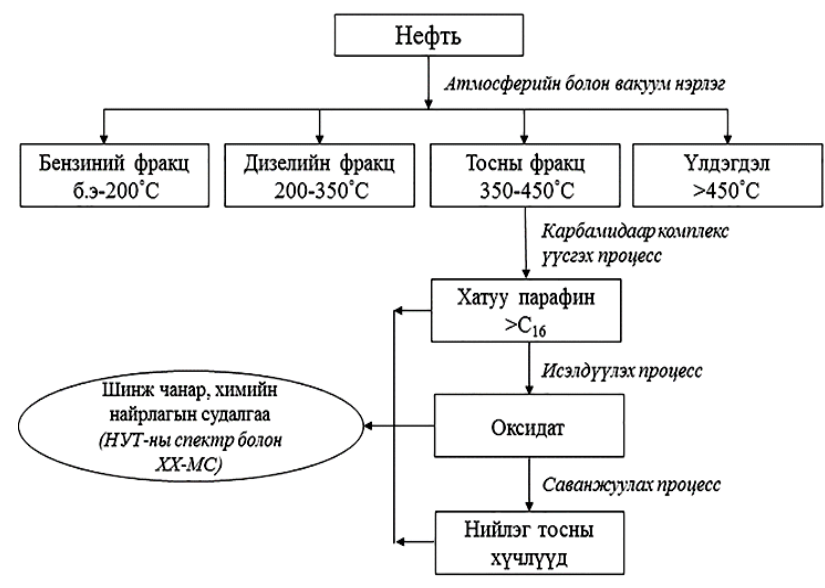

Зураг 1. Цагаан-Элсний ордын нефтиэс нийлэг тосны хүчил гарган авах схем

тооцоолов [17, 18]. Исэлдүүлэн гарган авсан оксидатад агуулагдах бага молекулт хүчиллэг нэгдлүүдийг усаар угааж зайлуулсны дараа оксидатыг $\mathrm{Na}_{2} \mathrm{CO}_{3}$ болон шүлтийн уусмалаар шат дараалан саванжуулах замаар дээд тосны хүчлүүдийн натрийн давсыг бусад хольцуудаас салган авав. Саванжуулсан оксидатыг үл саванжих хэсгийн хольцуудаас нь автоклавт 2 цагийн турш $180^{\circ} \mathrm{C}$-т тавих, усны уураар нэрэх дамжлагуудаар салгасан ба дараа нь концентрацитай хүхрийн хүчлээр задлан НТХ-үүдийн хольцыг гарган авсан.

Нефтийн хатуу парафин болон гарган авсан нийлэг тосны хүчлийн найрлагыг "Bruker- ALPHA II" маркийн нил улаан туяаны спектрометрийн багаж [19] болон "GC Thermo Scientific-Trace 1310" маркийн хийн хроматограф - масс спектрометрийн (XX-MC) багажны тусламжтайгаар тодорхойлсон (TSQ8000 - triple Quandrupole MS" детектор, 30м х

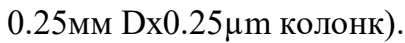

\section{ҮР ДҮН, ХЭЛЭЛЦҮУЛЭГ}

Цагаан-Элсний ордын нефтийг ус болон механик хольцоос салган урьдчилан боловсруулсны дараа физик-химийн үзүүлэлтүүдийг стандарт арга зүйн дагуу тодорхойлж дүнг Хүснэгт 1-д үзүүлэв.

Хүснэгт 1-ээс харахад Цагаан-Элсний ордын нефть нь парафины агуулга ихтэй (16.8 мас.\%) тул өндөр температурт царцдаг $\left(20^{\circ} \mathrm{C}\right)$, өтгөн зуурамтгай $(61.2$

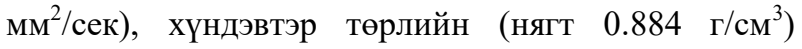
нефтийн ангилалд хамаарч байна $[11,20]$. Иймд парафины агуулга өндөртэй манай орны нефтийн онцлог шинж чанарт үндэслэн түүнээс хатуу парафин ялган авч бүтээгдэхүүн гарган авах арга, технологийг бий болгох нь чухал асуудлын нэг юм.

\section{н-Парафины найрлага, иинж чанарын судалгаа:}

Хэвлэлийн материалаас харахад $\mathrm{C}_{20}-\mathrm{C}_{35}$ бүхий нүүрстөрөгчийн атом агуулсан хатуу парафин НТХ гарган авахад тохиромжтой түүхий эд болдог бөгөөд эдгээр нь $350-450^{\circ} \mathrm{C}$-ийн хязгаарт нэрэгдэх тосны фракцад агуулагддаг. 
Хуснэгт 1. Цагаан-Элсний ордын нефтийн физикхимийн ҮзУҮлэлт

\begin{tabular}{|c|c|c|}
\hline № & Үзүүлэлтүүд & Утга \\
\hline 1 & Нягт, $20^{\circ} \mathrm{C}-д$, г $/ \mathrm{cm}^{3}$ & 0.884 \\
\hline 2 & $\begin{array}{l}\text { Кинематик зууралдлага, } 50^{\circ} \mathrm{C}-д, \text { мм }^{2} / \\
\text { сек, }\end{array}$ & 61.20 \\
\hline 3 & $\begin{array}{l}\text { Дөл үүсгэх температур, }{ }^{\circ} \mathrm{C} \\
\text { /задгай тигелийн аргаap/ }\end{array}$ & 58.00 \\
\hline 4 & Царцах температур, ${ }^{\circ} \mathrm{C}$ & 20.00 \\
\hline 5 & Бүлгийн бүрэлдэхүүн, мас.\% & \\
\hline \multirow{9}{*}{6} & Асфальтен & 0.84 \\
\hline & Давирхай & 13.70 \\
\hline & Toc & 83.63 \\
\hline & Хатуу парафин, мас.\% & 16.80 \\
\hline & Фракцуудын гарц, мас.\% & \\
\hline & б.э- $250^{\circ} \mathrm{C}$ & 9.80 \\
\hline & $250-350^{\circ} \mathrm{C}$ & 16.30 \\
\hline & $350-450^{\circ} \mathrm{C}$ & 20.16 \\
\hline & $>450$ & 53.84 \\
\hline
\end{tabular}

Иймд Цагаан-Элсний ордын нефтийн $350-450^{\circ} \mathrm{C}$-д нэрэгдэх тосны фракциас карбамидаар комплекс үүсгэх замаар гарган авсан хатуу парафины физикхимийн Үзүүлэлтийг ГОСТ 23683-89 техникийн шаардлагын дагуу тодорхойлж дүнг Хүснэгт 2-т, нүүрсустөрөгчдийн найрлагыг XX-МС-ийн багажит анализын аргаар тодорхойлж Зураг 2 болон Хүснэгт 3-т үзүүлэв. Судалгааны дүнгээс харахад нефтийн $350-450^{\circ} \mathrm{C}$-д нэрэгдэх тосны фракцад агуулагдах парафины эгнээний нүүрсустөрөгчдийн агуулга 34.28 мас.\% байв. Эдгээр нь үнэргүй, $43.5^{\circ} \mathrm{C}$-д царцдаг, $52.5^{\circ} \mathrm{C}$-д хайлдаг цагаан өнгийн тосорхог эд бөгөөд фракцийн найрлага болон физик үзүүлэлтүүд нь НТХ-ийн үйлдвэрлэлд ашигладаг С маркийн парафины шаардлагад нийцэж байна [21].

Цагаан-Элсний ордын нефтийн тосны фракциас ялгасан парафины XX-MC-ийн шинжилгээний дүнгээс харахад нефтийн тосны фракциас ялгасан парафины найрлаганд $\mathrm{C}_{17}-\mathrm{C}_{33}$ бүхий нүүрстөрөгчийн атом агуулсан н-алканууд 89.05 хувийг эзэлж байгаa бөгөөд молекул массын хувиарлалт нь “унимодаль" шинжтэй ба максимум нь $\mathrm{C}_{23}-\mathrm{C}_{28}$ бүхий нүүрстөрөгчийн атомууд дээр тохиож байгаа нь Зураг 2 болон Хүснэгт 2-оос харагдаж байна.

Цагаан-Элсний ордын нефтийн парафины нүүрсустөрөгчдийн найрлагаас үзэхэд манай орны

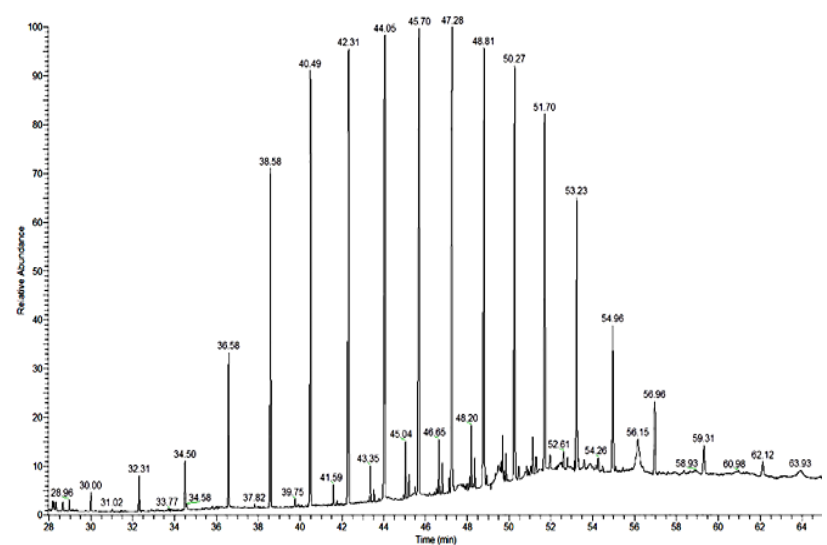

Зураг 2. Цагаан-Элсний ордын нефтийн тосны фракциас ялгасан н-парафины хроматограмм
Хуснэгт 2. Цагаан-Элсний ордын нефтийн 350-450

${ }^{\circ} \mathrm{C}$-д нэрэгдэх тосны фракииас ялгасан н-алканьл эгнээний нүҮрсустөрөгчдийн агуулга, мас.\%

\begin{tabular}{cccc}
\hline $\begin{array}{c}\text { С-ийн атомын } \\
\text { тоо }\end{array}$ & $\begin{array}{c}\text { Агуулга, } \\
\text { мас.\% }\end{array}$ & $\begin{array}{c}\text { С-ийн } \\
\text { атомын } \\
\text { тоо }\end{array}$ & $\begin{array}{c}\text { Агуулга, } \\
\text { мас.\% }\end{array}$ \\
\hline 17 & 0.40 & 26 & 9.19 \\
18 & 0.72 & 27 & 8.69 \\
19 & 0.97 & 28 & 8.19 \\
20 & 3.07 & 29 & 7.10 \\
21 & 6.79 & 30 & 5.40 \\
22 & 8.71 & 31 & 1.45 \\
23 & 9.06 & 32 & 0.58 \\
24 & 9.24 & 33 & 0.27 \\
25 & 9.22 & 34 & - \\
Нийт & 89.05 & & \\
\hline
\end{tabular}

өндөр парафинт нефтиэс ялгасан хатуу парафин нь HТX гарган авахад шинж чанар, найрлагын хувьд тохиромжтой түүхий эд болох нь харагдаж байна.

Парафиныг исэлдүҮлэн НТХ гарган авах урвалын зохимжтой горимыг тогтоох математик загварчлалын тооцоо: н-Парафиныг исэлдүүлэн НТХ гарган авахын тулд молекул хүчилтөрөгчийн оролцоотойгоор исэлдүүлэх ба исэлдэх урвалыг температур, хугацаа, исэлдүүлэгч агентын урсгалын хэмжээ, катализаторын хэмжээ зэргээс хамааруулан судалж, математик загварчлалын аргаар 2 фактораас $\left(2^{\mathrm{r}}=2^{2}=4\right.$ туршилт) хамааруулан явуулав. Үүнд:

- $x_{1}$ буюу хүчилтөрөгчийн урсгалын хурд, $\mathrm{Vo}_{2}$, л/ мин $\left(0.4<\left[\mathrm{O}_{2}\right]<0.6\right)$

- $x_{2}$ буюу катализаторын хэмжээ, \% (0.05 < [Mn-cat] $<0.1)$

Эдгээр хүчин зүйлийн нөлөөгөөр урвалын бүтээгдэхүүний гарц (оксидатын), оксидатын хүчлийн тоо зэрэг үзүүлэлтүүд хэрхэн өөрчлөгдөж байгааг, мөн тухайн процессод аль фактор нь илүү нөлөөлж байгааг дараах туршилтын загварыг ашиглаж тодорхойлж Хүснэгт 3-т үзүүлэв.

Үйлдвэрлэлийн процессын үед исэлдсэн бүтээгдэхүүний (оксидатын) хэмжээг хүчлийн тоогоор хянаж тодорхойлдог ба хүчлийн тоог 70 мг КОН/г хүрэх үед исэлдэх урвалыг явагдсан гэж үздэг [22]. Исэлдүүлэх урвалын явцыг 2 цаг тутамд дээж авч хүчлийн тоог тодорхойлох замаар

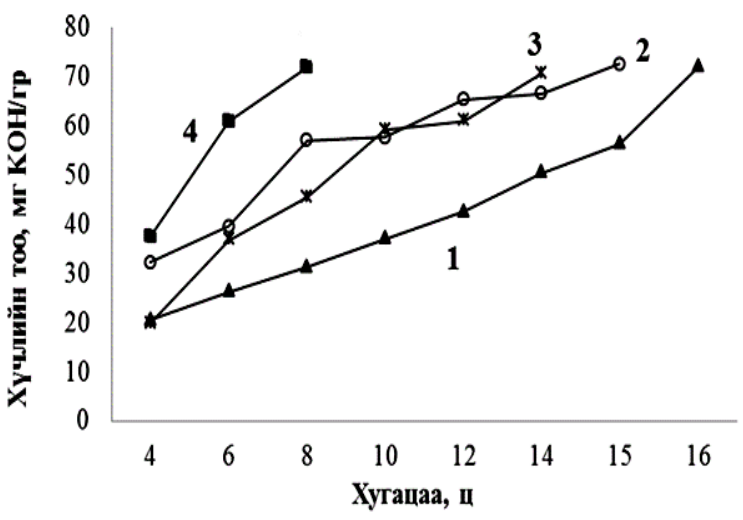

Зураг 3. Парафины исэлдэлтийн хүчлийн тоо хугаиааны хамаарал (1,2,3,4-туршилтын дугаар) 
ХУснэгт 3. Туршилтын загвар $2^{r}$ болон исэлдүүлэлтийн процессын дүн

\begin{tabular}{cccccccccc}
\hline Туршилт & $\mathrm{x}_{0}$ & $\mathrm{x}_{1}$ & $\mathrm{x}_{2}$ & $\mathrm{x}_{1}$ & $\mathrm{x}_{2}$ & $\mathrm{x}_{1 /} \mathrm{x}_{2}$ & Оксидатын гарц, \% & $\begin{array}{c}\text { Хугацаа, } \\
\text { цаг }\end{array}$ & $\begin{array}{c}\text { Хүчлийн тоо, } \\
\text { мг КОН/ } г\end{array}$ \\
\hline 1 & + & -1 & -1 & 0.4 & 0.05 & +1 & 88.2 & 16 & 70.2 \\
2 & + & +1 & -1 & 0.6 & 0.05 & -1 & 92.4 & 15 & 72.6 \\
3 & + & -1 & +1 & 0.4 & 0.1 & -1 & 93.5 & 14 & 70.6 \\
4 & + & +1 & +1 & 0.6 & 0.1 & +1 & 89.6 & 8.5 & 71.8 \\
\hline
\end{tabular}

Тайлбар: “+”- дээд түвщин, “-”- доод түвиин,

$x_{1}, x_{2}-$ кодчилсон утга, $x_{1}, x_{2}-$ туриилтын утга

Жнь: туршилт 1 дээр $x_{1}$ ракторын хамгийн бага утга буюу $0.4 \mathrm{л} /$ мин, $x_{2}$ факторын хамгийн бага утга

$C_{M n}, \%$ - 0.05 байхаар тооцож исэлдэх урвальг явуулах.

хянаж байв. Парафины исэлдүүлэх урвал нь цэвэр хүчилтөрөгчийн урсгал болон катализаторын хэмжээнээс хамааран 8-16 цаг үргэлжилж байв.

Исэлдэх урвалын хурд нь катализаторыг өгөх арга болон парафин дахь катализаторын концентраци ба найрлага, мөн үндсэн түүхий эдийн найрлагаас хамаарна. Катализаторыг урвалын системд өгөхдөө температурыг харьцангуй өндөр байхад (120-130 $\left.{ }^{\circ} \mathrm{C}\right)$ бага багаар дусаах ба урвал өдөөгдөж байгаа нь урвалын температур өсөж байгаагаар тодорхойлогдоно. Зураг 3-аас харахад туршилт 1 буюу хүчилтөрөгчийн урсгалын хурд болон катализаторын хэмжээг хамгийн доод төвшнөөр авахад исэлдүүлэлтийн процесс хамгийн удаан (16 цаг) явагдаж 16 цагийн дараа хүчлийн тоо 70.2 мг $\mathrm{KOH} / г$-д хүрч байв. Хамгийн их утгаар буюу хүчилтөрөгчийн урсгалыг 0.6 л/мин, катализаторын хэмжээг 0.1\%-иар авахад исэлдүүлэлтийн процесс 8 цаг 30 мин явагдаж хүчлийн тоо 71.8 болж байв. Туршилт 2 ба 3-ын хувьд хүчлийн тооны өсөлт харьцангуй нэг түвшинд, урвал явагдаж буй хугацаа ч ойролцоо (14 ба 15 цаг) байв.

$$
y=b_{0}+\sum_{i=1}^{n} b_{i} x_{i}=b_{0} x_{0}+b_{i} x_{i}+b_{n} x_{n} \quad\left(x_{0}=1\right)
$$

Энд: $b_{0}, b_{i}-$ корреляцийн коэффициент,

у - оксидатын гарц,

$x_{i}-x_{n}$ урвалд нөлөөлөх хүчин зүйлс.

Цагаан-Элсний ордын нефтиэс ялгасан парафины нүүрсустөрөгчдийг исэлдүүлж НТХ гарган авах процесст нөлөөлж буй хүчин зүйлүүдийн нөлөөллийг Регрессийн тэгшитгэлээр илэрхийлж болно.

Регрессийн тэгшитгэлийг бодоход исэлдүүлэлтийн процессын үр дүнг ашигладаг бөгөөд энэ тохиолдолд исэлдүлэлтийн процессын бүтээгдэхүүн болох оксидатын гарц ба урвал явагдсан хугацааг сонгон тооцоолж Хүснэгт 4-д

Хүснэгт 4. Коррелящчийн коэффицичентийн харгалзах утга

\begin{tabular}{cccccc}
\hline $\begin{array}{c}\text { Тэгшитгэлийн } \\
\text { дугаар }\end{array}$ & $\begin{array}{c}\text { Нөлөөлөх } \\
\text { хүчин } \\
\text { зүйлс }\end{array}$ & $\mathrm{b}_{0}$ & $\mathrm{~b}_{1}$ & $\mathrm{~b}_{2}$ & $\mathrm{~b}_{1.2}$ \\
\hline 1 & Хугацаа & 13.33 & 1.68 & 2.1 & -1.1 \\
2 & $\begin{array}{c}\text { Оксидатын } \\
\text { гарц }\end{array}$ & 90.94 & 0.08 & 0.6 & -2.0 \\
\hline
\end{tabular}

Үзүүлэв. Регрессийн тэгшитгэлийг туршилтын дүнгээр тооцоолон бичвэл:

$$
\begin{aligned}
& \mathrm{y}^{1}=13.325+1.675 \mathrm{x}_{1}+2.125 \mathrm{x}_{2}-1.125 \mathrm{x}_{1} \mathrm{x}_{2} \\
& \mathrm{y}^{2}=90.935+0.075 \mathrm{x}_{1}+0.625 \mathrm{x}_{2}-2.025 \mathrm{x}_{1} \mathrm{x}_{2}
\end{aligned}
$$

Дээрх 2 тэгшитгэлээс үзэхэд катализаторын хэмжээг илэрхийлэх $b_{2}$ коэффициент нь хүчилтөрөгчийн урсгалын хурдыг илэрхийлэх $b_{1}$ коэффицентээс их байгаa нь парафиныг исэлдүүлэх процессод катализаторын концентрацийн хэмжээ илүҮ нөлөөлж байгааг харуулж байна. Цагаан-Элсний ордын нефтиэс ялгасан хатуу парафины исэлдүүлэх урвалын тохиромжтой горим - катализаторын хэмжээ 0.1 мас.\% $\mathrm{Mn}$, урвал явагдах орчны температур $105-140^{\circ} \mathrm{C}$, хүчилтөрөгчийн урсгалын хурд 0.6 л/мин болохыг тогтоов.

\section{Нийлэг тосны хүчлийн найрлага, шинжс чанарын} судалгаа:

Цагаан-Элсний ордын нефтиэс ялгасан парафины найрлагыг, дээрх горимын дагуу исэлдүүлэн гарган авсан оксидатын найрлагатай харьцуулан НУТ-ны спектрометрийн аргаар судлан Зураг 4-т харуулав. Спектрийн дүнгээс харахад 2852, $2920 \mathrm{~cm}^{-1}$ шингээлтийн мужуудад алканы эгнээний $\mathrm{CH}_{2}, \mathrm{CH}_{3}$ бүлгүүдийн валентын хэлбэлзлийн шингээлтийн шугам, $1465 \mathrm{~cm}^{-1}$ мужид $\mathrm{CH}_{3}$ метилийн бүлгийн деформацийн хэлбэлзлийн шингээлтийн шугамууд, $1176 \mathrm{~cm}^{-1}$ мужид $\mathrm{CH}_{2}$ метилений бүлгийн шингээлтийн өвөрмөц шугамууд, $721 \mathrm{~cm}^{-1}$ мужид $\left(\mathrm{CH}_{2}\right)_{\mathrm{n}}$ полиметилений хэлхээний метилений бүлгийн шингээлтүүд тус тус илэрч байна. Мөн исэлдэлтийн урвалын дүнд гарган авсан оксидатын

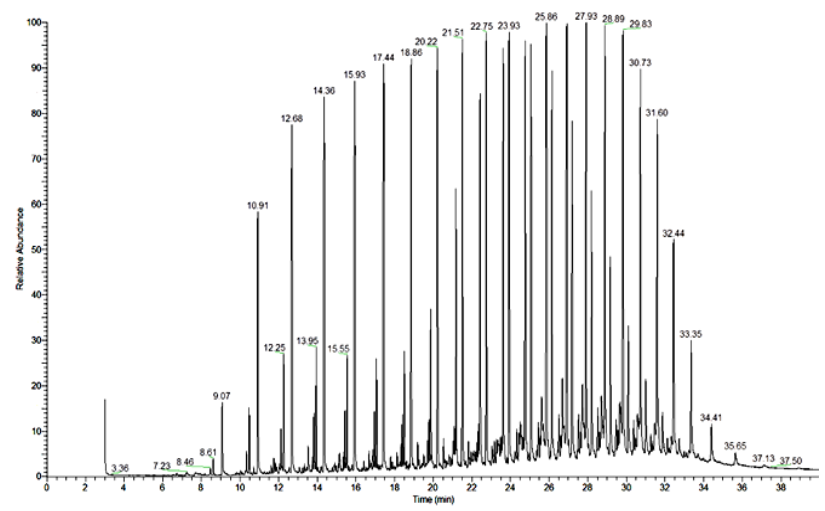

Зураг 5. Цагаан-Элсний ордын нефтийн н-парафины исэлдүҮлэлтээр гарган авсан НTX-ийн хроматограмм 

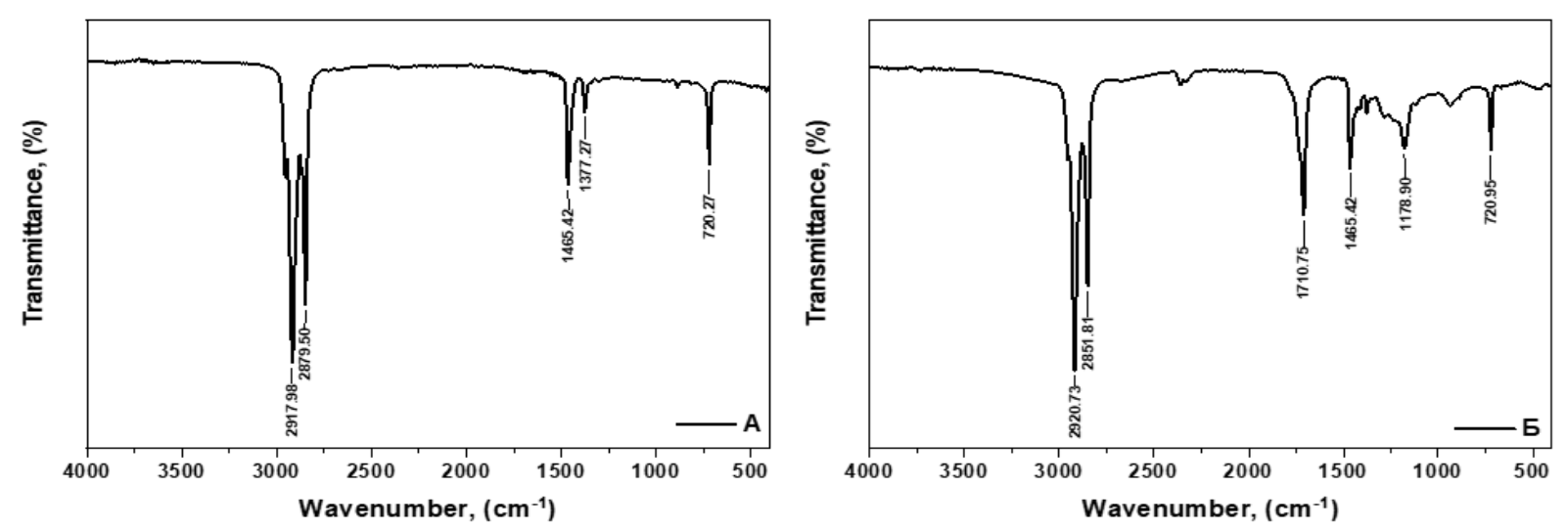

Зураг 4. а. Парафины НУТ спектр б. Оксидатын НУТ спектр

НУТ-ны спектрт $1710 \mathrm{~cm}^{-1}$ мужид карбонил бүлгийн шингээлтийн зурвас илэрч байгаa нь (Зураг 4б) исэлдүүлэх процессын дүнд монокарбон хүчлүүд зонхилсон хүчилтөрөгч агуулсан нэгдлүүд үүсч байгааг цэвэр парафины НУТ-ийн спектртэй (Зураг 4a) харьцуулахад тодорхой харагдаж байна $[19,23]$. Судлагдаж буй нефтийн парафиныг исэлдүүлэн

$\boldsymbol{X}_{\boldsymbol{Y}}$ снэгт 5. Парафины исэлдҮҮлэлтээр гарган авсан НТХ-ийн нҮҮрсустөрөгчдийн найрлага, мас.\%

\begin{tabular}{|c|c|c|c|}
\hline Хүчлийн нэршил & $\begin{array}{c}\text { Ерөнхий } \\
\text { томьёо: } \\
\mathrm{C}_{\mathrm{n}} \mathrm{H}_{2 \mathrm{n}+1} \mathrm{COOH}\end{array}$ & $\begin{array}{c}\text { Баригдах } \\
\text { хугацаа, } \\
\text { мин }\end{array}$ & $\begin{array}{l}\text { Агуулг } \\
\text { амас.\% }\end{array}$ \\
\hline Энантын хүчил & $\mathrm{C}_{6} \mathrm{H}_{13} \mathrm{COOH}$ & 9.07 & 0.46 \\
\hline $\begin{array}{l}\text { Каприлийн } \\
\text { хүчил }\end{array}$ & $\mathrm{C}_{7} \mathrm{H}_{15} \mathrm{COOH}$ & 10.91 & 1.56 \\
\hline Пеларгоны хүчил & $\mathrm{C}_{8} \mathrm{H}_{17} \mathrm{COOH}$ & 12.68 & 2.35 \\
\hline Каприний хүчил & $\mathrm{C}_{9} \mathrm{H}_{19} \mathrm{COOH}$ & 14.36 & 2.93 \\
\hline $\begin{array}{l}\text { Ундецилийн } \\
\text { хүчил }\end{array}$ & $\mathrm{C}_{10} \mathrm{H}_{21} \mathrm{COOH}$ & 15.93 & 3.23 \\
\hline Лауриний хүчил & $\mathrm{C}_{11} \mathrm{H}_{23} \mathrm{COOH}$ & 17.44 & 3.33 \\
\hline $\begin{array}{l}\text { Тридецилийн } \\
\text { хүчил }\end{array}$ & $\mathrm{C}_{12} \mathrm{H}_{25} \mathrm{COOH}$ & 18.86 & 3.34 \\
\hline $\begin{array}{l}\text { Миристиний } \\
\text { хүчил }\end{array}$ & $\mathrm{C}_{13} \mathrm{H}_{27} \mathrm{COOH}$ & 20.22 & 3.4 \\
\hline $\begin{array}{l}\text { Пентадецилийн } \\
\text { хүчил }\end{array}$ & $\mathrm{C}_{14} \mathrm{H}_{29} \mathrm{COOH}$ & 21.51 & 3.41 \\
\hline $\begin{array}{l}\text { Пальмитины } \\
\text { хүчил }\end{array}$ & $\mathrm{C}_{15} \mathrm{H}_{31} \mathrm{COOH}$ & 22.75 & 3.41 \\
\hline $\begin{array}{l}\text { Маргарины } \\
\text { хүчил }\end{array}$ & $\mathrm{C}_{16} \mathrm{H}_{33} \mathrm{COOH}$ & 23.93 & 3.44 \\
\hline Стеарины хүчил & $\mathrm{C}_{17} \mathrm{H}_{35} \mathrm{COOH}$ & 25.06 & 3.21 \\
\hline $\begin{array}{l}\text { Нонадецилийн } \\
\text { хүчил }\end{array}$ & $\mathrm{C}_{18} \mathrm{H}_{37} \mathrm{COOH}$ & 26.14 & 2.81 \\
\hline Арахины хүчил & $\mathrm{C}_{19} \mathrm{H}_{39} \mathrm{COOH}$ & 27.19 & 2.24 \\
\hline $\begin{array}{l}\text { Генэйкоцилын } \\
\text { хүчил }\end{array}$ & $\mathrm{C}_{20} \mathrm{H}_{41} \mathrm{COOH}$ & 28.20 & 1.79 \\
\hline Бегений хүчил & $\mathrm{C}_{21} \mathrm{H}_{43} \mathrm{COOH}$ & 29.17 & 1.22 \\
\hline $\begin{array}{l}\text { Трикоцилийн } \\
\text { хүчил }\end{array}$ & $\mathrm{C}_{22} \mathrm{H}_{45} \mathrm{COOH}$ & 30.10 & 0.88 \\
\hline $\begin{array}{l}\text { Лигноцерины } \\
\text { хүчил }\end{array}$ & $\mathrm{C}_{23} \mathrm{H}_{47} \mathrm{COOH}$ & 31.00 & 0.53 \\
\hline $\begin{array}{l}\text { Пентакоцилийн } \\
\text { хүчил }\end{array}$ & $\mathrm{C}_{24} \mathrm{H}_{49} \mathrm{COOH}$ & 31.87 & 0.39 \\
\hline Церотиний хүчил & $\mathrm{C}_{25} \mathrm{H}_{51} \mathrm{COOH}$ & 32.74 & 0.16 \\
\hline Нийт тосны хүчлү & $\begin{array}{r}\mathrm{C}_{7}-\mathrm{C}_{26} \text { фракц } \\
\mathrm{C}_{10}-\mathrm{C}_{20} \text { фракц }\end{array}$ & \multicolumn{2}{|c|}{$\begin{array}{l}44.09 \text { мас. } \% \\
34.75 \text { мас. } \%\end{array}$} \\
\hline Исэлдээгүй н-алка & ууд $\mathrm{C}_{11}-\mathrm{C}_{29}$ & \multicolumn{2}{|c|}{44.13 мас. $\%$} \\
\hline Бусад нэгдлүүд & & \multicolumn{2}{|c|}{11.78 мас. $\%$} \\
\hline
\end{tabular}

гарган авсан оксидатыг цааш саванжуулах болон шат дараалан боловсруулах замаар оксидат, үл исэлдсэн нэгдлүүдээс салган дээд тосны фракцийг ялган авсан. Парафины исэлдүүлэлтийн дүнд гарган авсан дээд тосны хүчлийг метилжүүлэх замаар XXMC-ийн аргаар судалж хроматограммыг Зурагт 5-д, тосны хүчлийн агуулгыг Хүснэгт 5-д харуулав.

Хүснэгт 5-аaс харахад Цагаан-Элсний ордын нефтийн парафины исэлдүүлэлтээр гарган авсан HTX-ийн найрлаганд $\mathrm{C}_{7}-\mathrm{C}_{26}$ атом бүхий $\mathrm{HTX-үүд}$ таньж тодорхойлогдсон. Хэвлэлийн материалаас Үзэхэд оксидатыг боловсруулсны дараах НТХ-ийн найрлаганд $\mathrm{C}_{4}-\mathrm{C}_{28}$ хүртэл нүүрстөрөгчийн атомын тоотой шугаман бүтэцтэй монокарбон хүчлүүд (30$40 \%)$, изо- бүтэцтэй монокарбон хүчлүүд (15-25\%), дикарбоны хүчлүүд (4-5\%), бага хэмжээний окси-, кето-, ханаагүй хүчлүүд болон саванжаагүй үлдсэн бодисууд агуулагддаг байна. Бидний судалгааны дүнд үүссэн монокарбон хүчлийн агуулга 44.09 мас.\% бөгөөд үүнээс $\mathrm{C}_{10}-\mathrm{C}_{18}$ бүхий монокарбон хүчлүүд зонхилж байна (34.75 мас.\%).

Энэ нь гадаргуугийн идэвхт үйлчлэлтэй угаагч бэлдмэлүүдийн үйлдвэрлэлд өргөнөөр хэрэглэгддэг нефть химийн синтезийн чухал түүхий эд болох $\mathrm{C}_{10}-\mathrm{C}_{20}$ найрлага бүхий дээд тосны хүчлийн фракцийг гарган авахад зохимжтойг харуулж байна. Бусад хүчилтөрөгчит нэгдлүүд харьцангуй бага $11.78 \%$ хэмжээтэй Үүсэж байгаa нь урвал монокарбон хүчил үүсэх чиглэл рүҮ түлхүу явагдсан байгааг гэрчлэх бөгөөд урвалд ороогүй үлдсэн н-парафины нүүрсустөрөгчдийг дахин исэлдүүлэлтийн процессод оруулах шаардлагатай юм. Нийлэг тосны хүчилд агуулагдаж байгаa $\mathrm{C}_{10}$-аac доош найрлага бүхий хүчлүүд савангийн чанарыг муутгадаг ба $\mathrm{C}_{10}-\mathrm{C}_{16}, \quad \mathrm{C}_{17}-\mathrm{C}_{20}$ бүхий нийлэг хүчлүүдийн фракцаас бэлтгэсэн савангийн уусмал арьсыг цочроохгүй сайн чанарын угаах үйлчлэлтэй ГИБ болдог.

Мөн $\mathrm{C}_{12}-\mathrm{C}_{18}$ фракцийн саван дээр үндэслэн гаргасан түрхлэг тос нь бусад төрлийн сайн чанарын тоснуудын үзүүлэлтүүдтэй харьцуулахад чанарын өндөр шаардлага хангадаг байна. Иймээс манай 
орны парафины агуулга өндөртэй Цагаан-Элсний ордын нефтиэс төрөл бүрийн салбарт ашиглагдах нийлэг тосны хүчлүүдийн нарийн фракцуудыг гарган авахад тохиромжтой болохыг тогтоолоо.

\section{ДҮГНЭЛТ}

Судалгаанд авсан Цагаан-Элсний XIV талбай дахь ордын газрын тосны $350-450^{\circ} \mathrm{C}$-д нэрэгдэх шууд нэрлэгийн фракциас карбамидаар комплекс үүсгэх аргаар хатуу парафиныг ялган авч, физик-химийн үзүүлэлтүдийг тодорхорйлоход НТХ-ийн үйлдвэрлэлд ашиглагддаг С-маркийн парафины ангилалд (ГОСТ 23683-89) хамаарагдаж байна.

Цагаан-Элсний ордын нефтийн $350-450^{\circ} \mathrm{C}$-д нэрэгдэх тосны фракцаас ялгасан н-парафиныг исэлдүүлэх урвалын тохиромжтой горимыг катализаторын $\quad$ хэмжээ 0.1 мас.\% (прафинд тооцсоноор), урвал явагдах орчны температурыг 105 $-140^{\circ} \mathrm{C}$, хүчилтөрөгчийн урсгалын хурдыг 0.6 л/мин болохыг тогтоов.

Исэлдүүлэх урвалын зохимжтой горимыг математик загварчлалын аргыг ашиглан 2 фактораас хамааруулан судалж регрессын тэгшитгэлээр исэлдүүлэх процессод нөлөөлж буй хүчин зүйлүүдийн нөлөөллийг тооцоолоход катализаторын хэмжээ чухал үүрэг гүйцэтгэж байгааг судлан тогтоолоо.

Монгол орны өндөр парафинт нефтиэс ялгасан хатуу парафины исэлдүүлэлтээр гадаргуугийн идэвхт үйлчлэлтэй угааг бэлдмэлүүдийн үйлдвэрлэлд өргөнөөр хэрэглэгддэг нефть химийн синтезийн чухал түүхий эд болох $\mathrm{C}_{10}-\mathrm{C}_{20}$ найрлага бүхий тосны дээд хүчлүүдийн фракцуудыг 40 хувийн гарцтайгаар синтезлэн гарган авах боломжтойг судлан тогтоолоо.

\section{АШИГЛАСАН МАТЕРИАЛ}

1. Ф.Азингер (1959). Парафиновые углеводороды. Химия и технология. Изд. Гостоптехиздат, Москва. х.369.

2. K.R.Lange. Surfactans (1997). A Practical Handbook. Hanser. Munich. x.237.

3. М.М.Сухорослова, В.Т.Новиков, \& В.Г.Бондалетов (2002). Лабораторный практикум по химии и технологии органических веществ. Изд. ТПУ, Томск. х.132.

4. М.Ю.Субочева, А.П.Ликсутина и др (2009). Химическая технология органических веществ. Учебное пособие, Изд. ТГТУ, Тамбов. х.19-20.

5. K.Liao, Y.Cong, L.Kang and et.al (2008). The mechanism of paraffin oxidation. Journal of Petroleum Science technology. Vol.26(15). x.18521858. https://doi.org/10.1080/10916460701426056

6. S.J.Purohit, Dr.Milind Pradhan (2013). Paraffin Oxidation studies. International Journal of Engineering innovation and research. Vol.2(1). $\mathrm{x} .75$
7. Р.А.Галимова, А.А.Гайфуллин, Х.Э.Харлампиди (2007). Окисление алканов до синтетических жирных кислот. Учебное пособие. Изд. КГТУ, Казань. х.114-116

8. Б.Ширчин, М.Туяа, Б.Хонгорзул, Б.Хулан. Б.Пүрэвсүрэн (2013). Нефтийн хими ба технологийн үндэс. Соёмбо принтинг, УБ. х.537.

9. Б.Хонгорзул, А.К.Головко, Л.В.Горбунова, В.Ф.Камьянов, Б.Пүрэвсүрэн (2007). Нефти Монголии и рациональные направления их переработки. Технологии нефти и газа. Москва, Россия. Vol.43(6). х.492-502. https:// doi.org/10.1007/s10553-007-0086-7

10. П.Очирбат (2013). Монголын газрын тосны хайгуулын шинэ үе. УБ, х.480.

11. B. Shirchin., et al. (2003). A study on Main Physical and chemical Characteristics of East Mongolian Petroleum. Journal of the Korean Industrial and Engineering Chemistry. Vol.14(4). x.423-425. https://doi.org/10.1023/A:1024414330486

12. Д.Монхообор (2003). Нефть ба нефтийн бүтээгдэхүүний шинжилгээний арга. МУИС пресс, УБ. х.112.

13. B.Khulan, B.M.Bembeli, A.K.Golovko, B.Shirchin (2007). Deparaffinization of heavy fractions of high paraffins crude oils. Journal of Treatment Petroleum of Chemistry. Vol.7. х.28-31

14. М.К.Ибраев, А.В.Кириенко (2020). Изучение применимости карбамидной депарафинизация на нефти месторождении карачаганак и Складскозаречное. Chemical Sciences. Colloduium - journal. Vol.14(66) DOI: https://oi.org/10.24411/2520-6990 -2020-11901

15.Р.М.Долинская, К.В.Вишневский (2014). Технология и оборудование основного органического и нефтехимического синтеза. Учебно-методическое пособие. Изд. БГТУ, Минск. х.66

16.Б.Ганцэцэг, Б.Хонгорзул, Б.Хулан, Б.Мягмаргэрэл, М.Туяа (2019). Нефтийн хатуу парафиныг исэлдүүлэх судалгааны дүнгээс. "Газрын тос 2019" онол практикийн ХХY э/uний бага хурлын эрдэм иинжилгээний бүтээл.УБ. х.78-81.

17.И.М.Кузнецова и др (2005). Разработка технологии гетерогенной реакции в системе газжидкость. Учебное пособие $\kappa$ лабораторному практикуму по общей химической технологии. Казань.х.49.

18. Ч.Авдай, Д.Энхтуяа (2007). Судалгаa шинжилгээний ажил гүйцэтгэх арга зүй. Статистик боловсруулалт, математик загварчлал, оновчлол. УБ. х.368.

19. Д.Монхообор, Г.Батчимэг (2009). Молекулын бүтэц ба спектроскопи, Битпресс ХХК, УБ. x. 250 


\author{
20.Б.Хонгорзул (2008). Особенности состава \\ углеводородов и высокомолекулярных \\ соединении высокопарафинистых нефтей \\ Монголии. Doctoral dissertation, Институт \\ химии нефти СО РАН, Томск, ОХУ. х.118. \\ 21.ГОСТ 23683-2021. (2021). Парафины нефтяные \\ твердые. Технические условия Российский \\ институт стандартизации, Моска. х. 24
}

22. Y.Cong, W.Huang (2010). Study on kinetics of paraffin-catalyzed oxidation reaction. Petroleum science and technology, Vol.28(4). x.393-400. DOI: https://doi.org/10.1080/10916460903070728

23. Ю.П.Дормидонтов (2001). Методы УФ, ИК и ЯМР спектроскопии и их применение в органической химии. Учебное пособие. Изд. Пермь, ПГУ химический факультет. х.79

\title{
Synthetic fatty acids from solid paraffin of Tsagaan-Els oil deposit
}

\author{
Byambasuren Gantsetseg, Bayanmunkh Myagmargerel, Murneren Tuya, \\ Bayasgalan Khulan, Batchuluun Khongorzul* \\ Laboratory of Organic Chemistry, Institute of Chemistry and Chemical Technology, \\ Mongolian Academy of Sciences, Ulaanbaatar 13330, Mongolia \\ *E-mail: khongorzul.b@mas.ac.mn \\ ORCID: 0000-0002-5953-3667
}

Submitted: 21.10 .2021

Reviewed: 24.10 .2021

Accepted: 28.12 .2021

\begin{abstract}
In this work, fatty acids, the raw materials for detergents, were obtained by the oxidation reaction of solid paraffin extracted from the Tsagaan-Els petroleum deposit of Mongolia. The oil fraction distilled from the crude oil at $350-450^{\circ} \mathrm{C}$ was 20.06 mass $\%$, and the solid paraffin was extracted from the oil fraction by complexation with urea with a yield of $34.28 \%$. Extracted solid paraffin contained hydrocarbons of $\mathrm{C}_{17}-\mathrm{C}_{34}$ and was unimodal in molecular mass distribution. Optimal conditions for the oxidation reaction of solid paraffin extracted from the oil fraction were determined by mathematical modeling depending on various reaction parameters and found to be $0.6 \mathrm{l} / \mathrm{min}$ for catalyst amount and 0.1 mass \% (from paraffin) for oxygen flow. The oxidation reaction of solid paraffin extracted from the Tsagaan-Els petroleum deposit resulted in a fraction of synthetic fatty acid with a yield of 44.09 mass \%. Infrared spectroscopic analysis of the synthetic fatty acids revealed that oxygen-containing compounds formed from the reaction were predominantly monocarboxylic acids and GC-MS studies have shown that these fatty acids are synthetic fatty acids containing carbon atoms of $\mathrm{C}_{7}-\mathrm{C}_{26}$. We report that it is possible to oxidize the solid paraffin of petroleum in our country to produce synthetic fatty acids, which are widely used in detergent production.
\end{abstract}

Keywords: synthetic fatty acid, paraffin, crude oil, catalyst, oxidate, mathematical modeling.

(C) The Author(s). 2021 Open Access This article is distributed under the terms of the Creative Commons Attribution 4.0 International License (https://creativecommons.org/licenses/by/4.0/), which permits unrestricted use, distribution, and reproduction in any medium, provided you give appropriate credit to the original author(s) and the source, provide a link to the Creative Commons license, and indicate if changes were made.

DOI: https://doi.org/10.5564/bicct.v4i9.1813 